http://jmscr.igmpublication.org/home/ ISSN (e)-2347-176x ISSN (p) 2455-0450

crossref DOI: https://dx.doi.org/10.18535/jmscr/v7i9.129

\title{
Role of autologous platelet-rich plasma (PRP) eye drops as monotherapy for the treatment of severe dry eye disease
}

\author{
Author \\ Dr Rishi Gupta, M.S. \\ Senior Resident, Sankara Nethralaya \\ Corresponding Author \\ Dr Rishi Gupta \\ Sankara Nethralaya
}

\begin{abstract}
Objective: To evaluate use of autologous platelet-rich plasma (PRP) eye drops for the treatment of severe dry eye disease.

Materials \& Method: This is a retrospective study conducted at a tertiary eye care centre. 30 patients with severe dry eye disease (DED) were included in this study. Data obtained from medical records of patients. Following information noted from medical records. Type of dry eye as evaporative DED (EDED) or aqueous deficient DED (ADDED). Following information were noted before treatment with PRP eye drops and on each follow up visits; OSDI score(Subjective symptoms), Corneal Fluorescein Staining (CFS), Tear Film Breakup Time (TBUT), Tear Meniscus Height (TMH) and Schirmer's score (SCH 1). Follow up done at 1 week, 1 month, 3 month and final follw up done at 6 months.

Results: Out of 30 cases 19 (63.3\%) were women, and 11 (36.6\%) were men.16 (53.3\%) had EDED, while $14(46.6 \%)$ had ADDED. 6 months of monotherapy with autologous PRP resulted reduction in dry eye symptoms in $28(93.3 \%)$ cases. CFS decreased in 23 (76.6\%) patients, TBUT improved in $26(86.6 \%)$ patients, tear meniscus height improved in 24 (80.0\%) patients and schirmers score improved in 16 (53.3 $\%)$ patients.
\end{abstract}

Conclusion: Autologous PRP is a effective treatment to improve sigh and symptoms of dry eye disease.

\section{Introduction}

Asian studies on dry eye showed that the prevalence of dry eyes is higher in Asian population than the western population and it is between $14.5 \%-93.2 \% .^{1-6}$ The prevalence of dry eye in India is ranging from $18.4 \%$ to $40.8 \% .^{1-3}$ This variation is because of lack of uniformity in the diagnostic criteria of dry eye. There are many etiological factors for dry eye like age, sex, smoking, occupational factors, geographical factors(high altitude, hot dry air) systemic diseases like Sjögren syndrome, Meibomian glands dysfunction, air conditioning, vitamin A deficiency etc. ${ }^{5,7-10}$ There are two main mechanisms that explain this ocular surface dysfunction: aqueous deficiency and excessive evaporation of the tear film. ${ }^{11}$ Preservative-free artificial eye drops are the main conventional treatment for dry eye providing ocular surface lubrication. However, they lack the complex composition of natural tears such as water, salts, lipids, proteins, and growth factors. ${ }^{12}$ 
Furthermore, taking into consideration that inflammation plays a main role in the pathogenesis of dry eye, other therapeutic alternatives such as topical corticosteroids and cyclosporine are used as a second-line treatment in severe dry eye. ${ }^{13,14}$ However, their use is limited due to several side effects, including ocular burns, strong irritation, increase of intraocular pressure, and glaucoma. ${ }^{15,16}$ Autologous serum and PRP have similar compositions, since they have various growth and healing factors present in the blood. ${ }^{17}$ However, autologous serum contains proinflammatory cytokines derived from leukocytes and monocytes, which may be harmful to patients with immunological disorders or diseases. ${ }^{18}$ Thus, the PRP is advantageous for not containing these immunoglobulins of the inflammation, and also for regulating the expression of several genes in the cellular communication and differentiation, improving the biological activity of the corneal epithelial cells when compared to the autologous serum. ${ }^{19}$ In addition, PRP becomes more effective when presenting higher indexes of growth factors such as: EGF (epithelial growth factor), vitamin A, neural growth factor (NGF), Insulin type I growth factor ${ }^{17}$ and platelet factor IV. ${ }^{20}$

\section{Materials \& Method}

This is a retrospective study conducted at a tertiary eye care centre. 30 patients with severe dry eye disease (DED) were included in this study. Data obtained from medical records of patients. Following information noted from medical records. Type of dry eye as evaporative DED (EDED) or aqueous deficient DED (ADDED). Following information were noted before treatment with PRP eye drops and on each follow up visits; OSDI score(Subjective symptoms), Corneal Fluorescein Staining (CFS), Tear Film Breakup Time (TBUT), Tear Meniscus Height (TMH) and Schirmer's score (SCH 1). Follow up done at 1 week, 1 month, 3 month and final follow up done at 6 months.

\section{Result}

30 patients were included in this study of which $11(36.6 \%)$ were male, $19(63.3 \%)$ were female, with age ranging from 18- 75 years (mean $49.52 \pm$ 13.98) (Table 1)

Table- 1 Characteristics of the Study Group

\begin{tabular}{|l|c|}
\hline Characteristics & No. \\
\hline Male & $11(36.6 \%)$ \\
\hline Female & $19(63.3 \%)$ \\
\hline Mean age (years) & $49.52 \pm 13.98$ \\
\hline
\end{tabular}

Out of 30 cases in present study, 13(43.3\%) cases had mixed DED followed by 11 cases $(36.6 \%)$ of EDED and 6(20\%) of ADDED. (Table 2)

Table- 2 Distributions of eyes according to Clinical Type

\begin{tabular}{|l|c|c|}
\hline Type & Number (30) & \% \\
\hline ADDED & 6 & $20 \%$ \\
\hline EDED & 11 & $36.6 \%$ \\
\hline MIXED DED & 13 & $43.3 \%$ \\
\hline
\end{tabular}

In present study Ocular Surface Disease Index (OSDI) was used to evaluate symptomatic improvements. Average OSDI reduced to $32 \pm 19.89$ from $76.21 \pm 15.85$ at 6 month post PRP therapy. 28(93.3\%) patients showed major improvement in symptoms. (Table 3 )

Table-3 Pre and Post Treatment OSDI Score

\begin{tabular}{|l|c|c|c|c|c|}
\hline \multirow{2}{*}{$\begin{array}{l}\text { OSDI } \\
\text { score }\end{array}$} & $\begin{array}{c}\text { No. day } \\
\text { (Pre-PRP } \\
\text { therapy) }\end{array}$ & 1week & $\begin{array}{c}\mathbf{1} \\
\text { month }\end{array}$ & $\begin{array}{c}\mathbf{3} \\
\text { month }\end{array}$ & $\begin{array}{c}\mathbf{6} \\
\text { month }\end{array}$ \\
\hline $\begin{array}{l}81- \\
100\end{array}$ & 15 & 13 & 7 & 2 & 1 \\
\hline $61-80$ & 8 & 8 & 9 & 5 & 1 \\
\hline $41-60$ & 6 & 7 & 5 & 9 & 7 \\
\hline $21-40$ & 1 & 2 & 6 & 9 & 12 \\
\hline $0-20$ & 0 & 0 & 3 & 5 & 9 \\
\hline Total & & & & & \\
\hline
\end{tabular}

Improvement in tear film breakup time (TBUT) represents the improvement in stability of the tear film. In present study TBUT improved in $76.6 \%$ (26) patients with initial mean value of $2.48 \pm 1.25$ seconds to $7.31 \pm 3.48$ seconds at 6 months of follow up. (Table 4) 
Table- 4 Pre and Post Treatment TBUT

\begin{tabular}{|l|c|c|c|c|c|}
\hline \multirow{2}{*}{$\begin{array}{l}\text { TBUT } \\
\text { Second } \\
\text { s }\end{array}$} & \multicolumn{5}{|c|}{ No. of patients } \\
\cline { 2 - 6 } & $\begin{array}{c}\text { O day } \\
\text { (Pre-PRP } \\
\text { therapy) }\end{array}$ & $\begin{array}{c}\mathbf{1} \\
\text { week }\end{array}$ & $\begin{array}{c}\mathbf{1} \\
\text { month }\end{array}$ & $\begin{array}{c}\mathbf{3} \\
\text { month }\end{array}$ & $\begin{array}{c}\mathbf{6} \\
\text { month }\end{array}$ \\
\hline $0-3$ & 25 & 18 & 11 & 8 & 6 \\
\hline$>3-6$ & 3 & 8 & 9 & 6 & 1 \\
\hline$>6-10$ & 2 & 3 & 8 & 11 & 16 \\
\hline$>10$ & 0 & 1 & 2 & 5 & 7 \\
\hline Total & 30 & \multicolumn{7}{|l}{} \\
\hline
\end{tabular}

Improvement in the tear meniscus height (TMH) in $80 \%$ (24) of the patients at 6 months. Initial mean score of $0.04 \pm 0.08 \mathrm{~mm}$ TMH was improved to $0.24 \pm 0.21 \mathrm{~mm}$ (Table 5)

Table- 5 Pre and Post Treatment TMH

\begin{tabular}{|l|c|c|c|c|c|}
\hline \multirow{2}{*}{ TMH } & \multicolumn{5}{|c|}{ No. of patients } \\
\cline { 2 - 6 } & $\begin{array}{c}\text { 0 day } \\
\text { (Pre-PRP } \\
\text { therapy) }\end{array}$ & $\begin{array}{c}\text { 1we } \\
\text { ek }\end{array}$ & $\begin{array}{c}\text { 1mont } \\
\text { h }\end{array}$ & $\begin{array}{c}\text { 3mont } \\
\mathbf{h}\end{array}$ & $\begin{array}{c}\text { 6mont } \\
\mathbf{h}\end{array}$ \\
\hline $\begin{array}{l}\text { Absen } \\
\mathrm{t}\end{array}$ & 20 & 20 & 15 & 9 & 6 \\
\hline $0-0.2$ & 9 & 8 & 9 & 11 & 8 \\
\hline $\begin{array}{l}0.3- \\
0.5\end{array}$ & 1 & 2 & 5 & 8 & 12 \\
\hline$>0.5$ & 0 & 0 & 1 & 2 & 4 \\
\hline Total & 30 & & & & \\
\hline
\end{tabular}

Corneal Fluorescein staining (CFS) positively correlates with severity of dry eye. At presentation mean CFS score was $2.72 \pm 0.45$ which reduced to $0.79 \pm 1.21$ and improvement was seen in $76.6 \%$ (23) of the patients. (Table 6)

Table -6 Pre and Post Treatment CFS

\begin{tabular}{|c|c|c|c|c|c|}
\hline \multirow{2}{*}{$\begin{array}{l}\text { CFS } \\
\text { (score) }\end{array}$} & \multicolumn{5}{|c|}{ No. of patients } \\
\hline & $\begin{array}{c}\text { 0 day } \\
\text { (Pre-PRP } \\
\text { therapy) }\end{array}$ & $\begin{array}{c}1 \\
\text { wee } \\
\mathbf{k}\end{array}$ & $\begin{array}{c}1 \\
\text { mont } \\
\text { h }\end{array}$ & 3month & 6month \\
\hline $\begin{array}{l}\text { Diffuse } \\
\text { (3) }\end{array}$ & 21 & 18 & 11 & 7 & 6 \\
\hline $\begin{array}{l}\text { Coarse } \\
\text { punctate } \\
\text { (2) }\end{array}$ & 8 & 5 & 4 & 1 & 1 \\
\hline $\begin{array}{l}\text { Fine } \\
\text { punctate } \\
\text { (1) }\end{array}$ & 1 & 7 & 2 & 5 & 3 \\
\hline $\begin{array}{l}\text { Absent } \\
(0)\end{array}$ & 0 & 6 & 13 & 17 & 20 \\
\hline Total & \multicolumn{5}{|l|}{30} \\
\hline
\end{tabular}

The initial mean Schirmer-1(SCH-1) value was $2.72 \pm 2.32 \mathrm{~mm}$ which was improved to $5 \pm 3.73$ $\mathrm{mm}$ after 6 months follow up and improvement was seen in $53.3 \%$ (16) of patients (Table 7)
Table -7 Pre and Post Treatment SCH Score

\begin{tabular}{|l|c|c|c|c|c|}
\hline \multirow{2}{*}{$\begin{array}{l}\text { SCH- } \\
\text { value }\end{array}$} & \multicolumn{6}{|c|}{$\begin{array}{c}\text { No. of patients } \\
\text { (Pre- } \\
\text { PRP } \\
\text { therapy) }\end{array}$} & 1week & 1month & 3month & 6month \\
\hline $0-2$ & 16 & 16 & 13 & 12 & 10 \\
\hline $3-4$ & 8 & 8 & 8 & 5 & 4 \\
\hline $5-10$ & 6 & 6 & 8 & 10 & 11 \\
\hline$>10$ & 0 & 0 & 1 & 3 & 5 \\
\hline Total & 30 & \multicolumn{7}{|l|}{} \\
\hline
\end{tabular}

\section{Discussion}

Dry eye disease is a multifactorial in nature with presentation in all the age groups. DED is one of the most common problems in patients attending the eye clinic. Its presentation varies from mild symptomatic to a severe disabling disease. The frequently reported complaints of patients with DED are sandy gritty eye irritation, burning, redness, intermittent sharp pain and photophobia but often there is no correlation between the signs and symptoms of dry eye disease. ${ }^{21}$ Although mild dry eye can be treated with the use of artificial tear substitutes but severe form of dry eye needs special attention and care because without sufficient tear film, irritation can translate to scratches on the cornea, Over time, corneal scratches due to dry eye can produce scarring and result in permanent vision loss. In extreme cases, the entire eye can be lost. Autologous PRP is a hemoderivative with a high concentration of platelets obtained through a relatively simple process, which requires minimal manipulation and no addition of any other particular substance. ${ }^{22}$ Platelets have a lot of important functions that are repairing tissue damage, coagulation prevents blood loss, secreting proteins, cytokines and other mediators; including tissue regeneration by cell migration, proliferation, and angiogenesis, and preventing infections because of its antianabolic action. They also have anti-inflammatory and analgesic action. ${ }^{23}$ In the present study there was symptomatic improvement (OSDI Score) in 93.3\% (28) of the patients, while CFS reduced in $76.6 \%$ (23), schirmer's score improved in $86.6 \%$ (26) after 6 months monotherapy treatment with PRP, these results are comparable to a study done 
by Jeorge L. Alio in $2017^{24}$ Ribeiro et. al. $(2016)^{25}$ showed improvement in $100 \%$ of patients in relation to symptoms, regarding Schirmer's test, $41.66 \%$ of patients showed improvement, $50 \%$ did not show alterations, and $8.33 \%$ had a reduced value after the test. Study by Alio $\mathrm{JL}^{26}$ (2007) showed symptomatic improvement in $89 \%$ of patients and significant improvement on tear meniscus and conjunctival hyperemia and a decrease or disappearance of corneal fluorescein staining. Sanchez-Avila $\mathrm{RM}^{27}$ showed a significant reduction $(\mathrm{P}<0.05)$ in OSDI scale $(41.86 \%)$. A study by Drew $\mathrm{VJ}^{28}$ showed $89 \%$ of patients using PRP eye drops four to six times per day reported subjective absence of DES symptoms. Benefits extended to include increased visual acuity, increased tear production, and improvements in ocular surface condition. A similar conclusion was reached by a study investigating the effect of this PRP on human lacrimal function ${ }^{29}$

\section{Conclusion}

Dry eye disease is like global warming which is increasing day by day with changing scenario and complexities which makes it difficult to manage it accurately. Subjective symptoms(OSDI) are seen to be improving within days of starting PRP eye drops, while the signs are seen improving within a week of starting treatment. Additional advantages as no added preservatives, autologous in origin makes PRP eye drop a tolerable and safe treatment to improve signs and symptoms in patients suffering from severe chronic DED.

Financial support: Nil

Acknowledgements: Nil

Prior presentation: None

Conflicts of interests: None

\section{References}

1. Sahai A, Malik P. Dry Eye: Prevalence and attributable risk factors in a hospitalbased population. Ind J Ophthalmol 2005; 53: 8791.
2. Gupta N, Prasad I, Jain R, D’Souza P. Estimating the prevalence of dry eye among Indian patients attending a tertiary ophthalmology clinic. Ann Trop Med Parasitol 2010; 104: 247-55.

3. Basak SK, Pal PP, Basak S, Bandyopadhyay A, Choudhury S, Sar S. Prevalence of Dry Eye Diseases in hospital-based population in West Bengal, Eastern India. J Indian Med Assoc. 2012; 110: 789-94.

4. Shimmura S, Shimazaki J, Tsubota K. Results of a population based questionnaire on the symptoms and lifestyles associated with dry eye. Cornea 1999; 18: 408-11.

5. McCarty CA, Bansal AK, Livingstone PM, Stanislavsky YL, Taylor HR. The epidemiology of dry eye in Melbourne, Australia. Ophthalmology 1998; 105: 11149.

6. Schaumberg DA, Sullivan DA, Buring JE, Dana MR. Prevalence of dry eye syndrome among US women. Am J Ophthalmol 2003; 136: 318-26.

7. Moss SE, Klein R, Klein BE. Prevalence of and risk factors for dry eye syndrome. Arch Ophthalmol 2000; 118: 1264-8.

8. Yazdani C, McLaughlin T, Smeeding JE, Walt J. Prevalence of treated dry eye disease in a managed care population. Clin Ther 2001; 23: 1672-82.

9. Schaumberg DA, Buring JE, Sullivan DA, Dana MR. Hormone replacement therapy and dry eye syndrome. JAMA 2001; 286: 2114-9.

10. Seedor JA, Lamberts D, Bergmann RB, Perry HD. Filamentary keratitis associated with diphenhydramine hydrochloride (Benadryl). Am J Ophthalmol 1986; 101: 376-7.

11. Hussain M, Shtein RM, Sugar A, Soong HK, Woodward MA, DeLoss K, Mian SI. Long-term use of autologous serum 50\% eye drops for the treatment of dry eye disease. Cornea. 2014;33(12):1245-51. 
12. Pan, Q., Angelina, A., Zambrano, A., et al. Autologous serum eye drops for dry eye. Cochrane Database Syst. Rev. 8:CD009327, 2013.

13. de Paiva, C.S., and Pflugfelder, S.C. Rationale for anti-inflammatory therapy in dry eye syndrome. Arq. Bras. Oftalmol. 71:89-95, 2008.

14. Dogru, M., and Tsubota, K. Pharmacotherapy of dry eye. Expert Opin. Pharmacother. 12:325-334, 2011.

15. Blomquist, P.H. Ocular complications of systemic medications. Am. J. Med. Sci. 342:62-69, 2011.

16. Zhou, X.Q., and Wei, R.L. Topical cyclosporine $\mathrm{A}$ in the treatment of dry eye: a systematic review and metaanalysis. Cornea. 33:760-767, 2014.

17. Wu TE, Chen JC, Hu C, Cheng CK. Easyto-prepare autologous platelet-rich plasma in the treatment of refractory corneal ulcers. Taiwan J Ophthalmol. 2015; 5(3):132-5.

18. Lopez-Garcia JS, Garcia-Lozano I, Rivas L, Martinez-Garchitorena J. Use of autologous serum in ophthalmic practice. Arch Soc Espanola Oftalmol. 2007; 82(1):9-20.

19. Freire V, Andollo N, Etxebarria J, Duran JA, Morales MC. In vitro effects5 of three blood derivatives on human corneal epithelial cells. Invest Ophthalmol Vis Sci. 2012; 53(9):5571-8.

20. Ribeiro MV, Barbosa FT, Ribeiro LE, Lacet CM, Lyra JM, Guedes VL, et al. Plateletrich plasma in diabetic dry eye disease. Rev Bras Oftalmol. 2016 ;75(4):308-13.

21. Barlett JD, Keith MS, Sudharshan L, Snedecor SJ. Associations between signs and symptoms of dry eye disease: a systematic review. 2015 Sep 16;9:1719-30. doi: 10.2147/OPTH.S89700.

22. Alio JL, Arnalich-Montiel F, Rodriguez AE. The role of "Eye Platelet Rich Plasma" (EPRP) for wound healing in ophthalmology.
Curr Pharm Biotechnol. 2012;13(7):125765.

23. Amable PR, Carias RBV, Teixeira MVT, da Cruz Pacheco Í, Corrêa do Amaral RJF, Granjeiro JM, Borojevic R. Platelet-rich plasma preparation for regenerative medicine: Optimization and quantification of cytokines and growth factors. Stem Cell Research \& Therapy. 2013;4(3):67

24. Jorge L. Alio,Alejandra E. Rodriguez,

Renan Ferreira-Oliveira, Dominika Wróbel Dudzińska, Ahmed A. Abdelghany Treatment of Dry Eye Disease with Autologous Platelet-Rich Plasma: A Prospective, Interventional, NonRandomized Study December 2017, Volume 6, Issue 2, pp 285-293

25. Ribeiro MV, Barbosa FT, Ribeiro LE, Lacet CM, Lyra JM, Guedes VL, et al. Plateletrich plasma in diabetic dry eye disease. Rev Bras Oftalmol. 2016;75(4):308-13.

26. Alio JL ${ }^{1}$, Colecha JR, Pastor S, Rodriguez A, Artola A. Symptomatic dry eye treatment with autologous platelet-rich plasma. 2007;39(3):124-9. Epub 2007 Mar 19.

27. Sanchez-Avila $\quad \mathrm{RM}^{1}$, Merayo-Lloves $\mathbf{J}^{1}$, Riestra $\quad \mathrm{AC}^{1}$, Anitua $\quad \mathrm{E}^{2,3}$, Muruzabal $\mathrm{F}^{2,3}$, Orive $\mathrm{G}^{3,4,5}$, Fernández-Vega $\mathrm{L}^{1}$. The Effect of Immunologically Safe Plasma Rich in Growth Factor Eye Drops in Patients with Sjögren Syndrome. 2017 Jun;33(5):391-399. doi: 10.1089/jop.2016.0166. Epub 2017 Apr 4

28. Drew VJ, Tseng CL, Seghatchian J, Burnouf T. Reflections on Dry Eye Syndrome Treatment: Therapeutic Role of Blood Products. Front Med (Lausanne). 2018;5:33. Published 2018 Feb 23. doi:10.3389/fmed.2018.00033

29. Avila MY. Restoration of human lacrimal function following platelet-rich plasma injection. Cornea (2014) 33(1):1821.10.1097/ICO.16. 